\title{
Sustainability assessment in transboundary context: Grand Ethiopian Renaissance Dam
}

\author{
Ayman F. Batisha ${ }^{1}$ (D)
}

Received: 20 June 2015/Accepted: 31 August 2015/Published online: 3 November 2015

(C) Springer International Publishing Switzerland 2015

\begin{abstract}
Sustainability assessment of Grand Ethiopian Renaissance Dam is assessed in transboundary context, using Rapid Impact Assessment Matrix (RIAM) technique. RIAM indicates that in both Physical and Chemical category and Biological and Ecological category, there are major negative impacts for both upstream and downstream countries. On the other hand, the RIAM indicates that in Sociological and Cultural category and Economic and Operational category will have a positive impact in upstream countries and negative impacts in downstream countries. The result is not intended to substitute for a full assessment of impacts, only to help shed light on some of the issues that deserve greater attention. The study concludes RIAM is a useful tool for decision makers as it is able to display the results of different development scenarios and produce transparent environmental solutions, even with very complex options. RIAM is an effective technique in environmental impact assessment, in particular with very complicated transboundary context as verified in this study. It is hoped that the realistic ability of RIAM in dealing with transboundary context is paved the way to full approval of both upstream and downstream countries in achieving sustainable development for shared water resources.
\end{abstract}

Keywords Sustainability assessment - Transboundary context - Espoo process - Rapid impact assessment matrix (RIAM) · Grand Ethiopian Renaissance Dam (GERD)

Ayman F. Batisha

abatisha@gmail.com

1 International Sustainability Institute, Cairo, Egypt

\section{Introduction}

Sustainability of Water Resources is focus on balancing the need for the development of water resources with the conservation of the environment in a way which will not compromise future generations. Attention to the sustainability, environmental and social aspects of dams and reservoirs must be a dominating concern pervading all our activities in the same way as the concern for structural and engineering safety. Pintér et al. (2012) stated that the Bellagio Sustainability Assessment and Measurement Principles have been developed through a similar expert group process, using the original Principles as a starting point. Using the largest and most reliable reference data of its kind and multilevel statistical techniques applied to large dams for the first time, Ansar et al. (2014) were successful in fitting parsimonious models to predict cost and schedule overruns. The outside view suggests that in most countries large hydropower dams will be too costly in absolute terms and take too long to build to deliver a positive risk-adjusted return unless suitable risk management measures outlined in this paper can be affordably provided. Policymakers, particularly in developing countries, are advised to prefer agile energy alternatives that can be built over shorter time horizons to energy megaprojects. Masden et al. (2010) illustrated that EU and UK legislation requires a cumulative impact assessment (CIA) as part of Environmental Impact Assessments (EIA). They proposed a conceptual framework to promote transparency in CIA through the explicit definition of impacts, actions and scales within an assessment. Raslanas et al. (2013) illustrated that Sustainability Assessment Systems (SAS) quantify the value of sustainability the buildings have become popular not only in planning a sustainable real estate development, but also in scientific research. De 
Montis (2014) studied the quality of the Strategic Environmental Assessment SEA reports on the energy and environmental planning tools used by Italian regions and provinces. Hanna et al. (2014) suggested that Free, Prior and Informed Consent (FPIC) processes need to be conducted at the earliest stages of project planning, and that Indigenous peoples should actively participate in impact assessment, monitoring and evaluation processes. Prenzel and Vanclay (2014) examined the contribution of the methodological approach used in social impact assessment (SIA) to conflict management.

\section{Sustainability analysis}

Sustainability assessment is a recent framing of impact assessment that places emphasis on delivering positive net sustainability gains now and into the future, MorrisonSaunders and Pope (2012). They postulate that sustainability assessment may be at the beginning of a phase of expansion not seen since environmental impact assessment was adopted worldwide. Policy assessment has spread rapidly around the world in the last few decades providing an opportunity for further innovation and understanding in the way in which assessment is conceived, practised and researched, Adelle and Weiland (2012). They suggest that the future agenda for both research and practices could attempt to straddle the theoretical approaches. The current state of the art of strategic environmental assessment (SEA), based on a review of existing literature, recent international conferences and practical experience has provided, Fundingsland Tetlow and Hanusch (2012). They suggest that the SEA community must learn to better identify and promote SEA's less tangible benefits beyond the immediate decision-making situation and that SEA practice would benefit from a more explicit understanding and communication of how it can add value to any given context. The progress in environmental impact assessment (EIA) over the last 40 years, with particular emphasis on the last 15-20 years, has been reviewed, Morgan (2012). He has discussed how the different areas of EIA practice and evaluation may be affected. Social impact assessment (SIA) is now conceived as being the process of managing the social issues of development, Esteves et al. (2012). They assert that the SIA community needs to revisit core concepts, such as culture, community, power, human rights, gender, justice, place, resilience and sustainable livelihoods. Health impact assessment (HIA) has matured as a form of impact assessment over the past two decades, Harris-Roxas et al. (2012). They present an overview of the historical and recent international developments in HIA, before detailing the existing strengths, weaknesses, opportunities and threats to practice.
Considering Lack of available data and time constraints arising from tight schedules create problems. Pastakia and Jensen (1998) discussed the criteria that might be used to evaluate EIA methods, and how RIAM measures up against these criteria. They showed that RIAM provides a system by which development options and scenarios can be rapidly evaluated. Ijäs et al. (2010) evaluated the applicability of the RIAM method (rapid impact assessment matrix) in the context of impact significance assessment. Upham and Smith (2014a, b) highlighted that the Rapid Impact Assessment Matrix (RIAM) has potential in policy deliberation. Kuitunen et al. (2008) examined how the results of Environmental Impact Assessment (EIA) and Strategic Environmental Assessment (SEA) could be compared using the Rapid Impact Assessment Matrix (RIAM) method. Mondal et al. (2010) showed that Rapid Impact Assessment Matrix (RIAM) comes under one of the options for the execution of EIA.

\section{Grand Ethiopian Renaissance Dam}

The Grand Ethiopian Renaissance Dam Project (GERDP) is located on the Blue Nile River in Ethiopia; about $40 \mathrm{~km}$ east of Sudan. GERD is located in the region of Benishangul-Gumaz, approximately $500 \mathrm{~km}$ north-west of the capital Addis Ababa. A location Map produced by Google Maps of GERDP is provided (Fig. 1). GERD will generate an artificial lake with a capacity of holding 63 billion cubic meter of water, twice the size of the largest natural lakeLake Tana-in Ethiopia. The power plant, expected to generate around 6000 megawatt (MW). The dam is designed that will be have a dimensions of a $145 \mathrm{~m}$ high and $1800 \mathrm{~m}$ long. A gravity-type dam composed of rollercompacted concrete and have spillway with two power houses; one on each side. High saddle dam with a $5 \mathrm{~km}$ long and $50 \mathrm{~m}$ high will support the Grand Millennium dam and reservoir. Table 1 presents Grand Renaissance Dam Data (Batisha 2013). Based on extensive literature review, Schoeters (2013) has assessed the possible impacts of the construction of the GERD- project. It focuses on environmental effects, resettlement, influence on livelihood and health, and international impact. Because so little information is available, International Rivers (2013), commissioned a local researcher to make a field visit to the dam site and the surrounding area. The resulting field report is not intended to substitute for an assessment of impacts, only to help shed light on some of the issues that deserve greater attention.

The Environmental impacts of Grand Ethiopian Renaissance Dam (GERD) and its Reservoir may be classified by several techniques. First, if it considers global impact; or transboundary impact; or local impact. Second, 
Fig. 1 A location map of the Grand Ethiopian Renaissance Dam Project (GERDP)

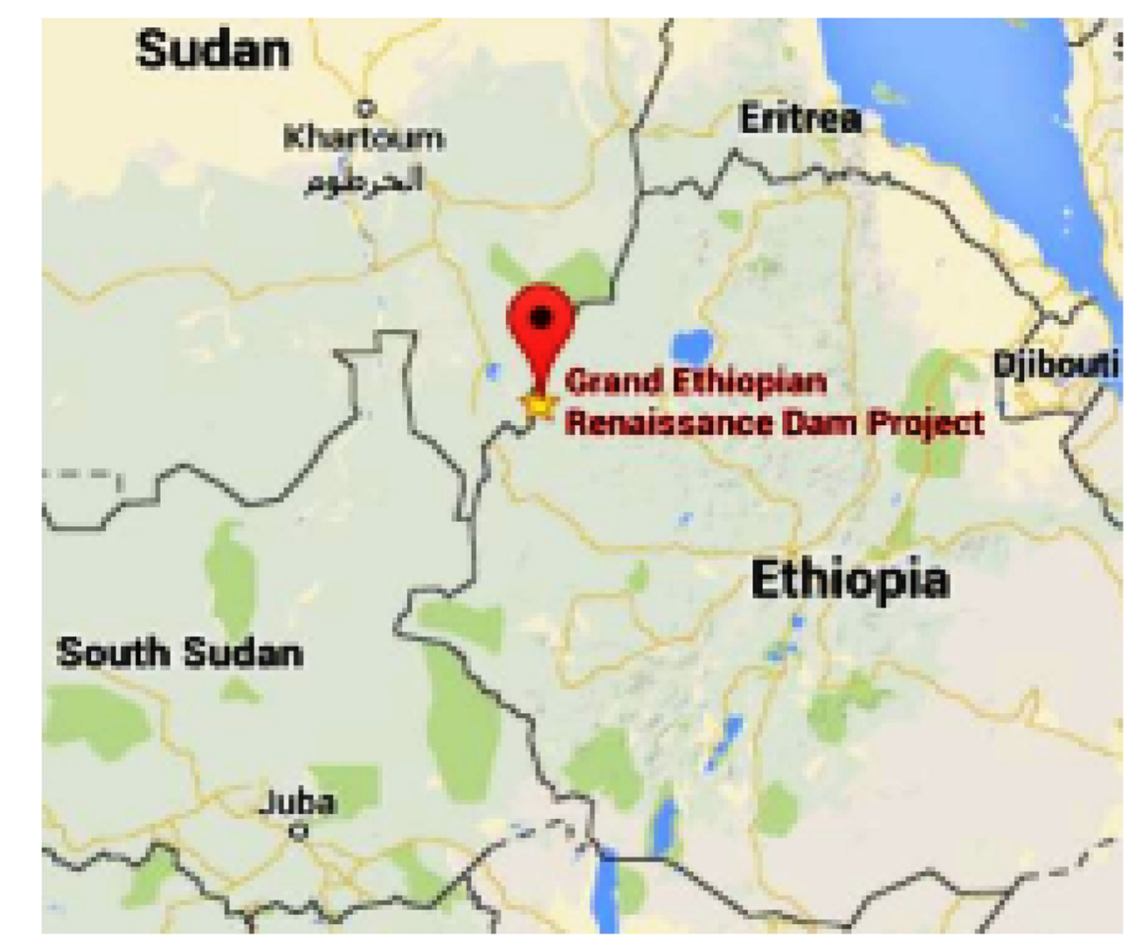

\begin{tabular}{|c|c|c|c|}
\hline & General & Item & Data \\
\hline 1 & Geography & $\begin{array}{l}\text { Country } \\
\text { Location } \\
\text { Coordinates }\end{array}$ & $\begin{array}{l}\text { Ethiopia } \\
\text { Benishangul-Gumuz region } \\
11^{\circ} 12^{\prime} 51^{\prime \prime} \mathrm{N} 35^{\circ} 05^{\prime} 35^{\prime \prime} \mathrm{E}\end{array}$ \\
\hline 2 & Type of dam & $\begin{array}{l}\text { Dam and spillways } \\
\text { Height } \\
\text { Length } \\
\text { Impounds }\end{array}$ & $\begin{array}{l}\text { Gravity, roller-compacted concrete } \\
145 \mathrm{~m}(476 \mathrm{ft}) \\
1800 \mathrm{~m}(5906 \mathrm{ft}) \\
\text { Blue Nile River }\end{array}$ \\
\hline 3 & Design and construction & $\begin{array}{l}\text { Construction began } \\
\text { Status } \\
\text { Concrete } \\
\text { Construction cost }\end{array}$ & $\begin{array}{l}\text { April } 2011 \\
\text { Preliminary construction } \\
\text { Use only domestically produced concrete } \\
\$ 4.8 \text { billion USD }\end{array}$ \\
\hline 4 & Saddle dam & Supporting dam \& reservoir & A $5 \mathrm{~km}$ long and $50 \mathrm{~m}$ high \\
\hline 5 & Reservoir & $\begin{array}{l}\text { Creates } \\
\text { Capacity }\end{array}$ & $\begin{array}{l}\text { Millennium reservoir } \\
63,000,000,000 \mathrm{~m}^{3}\end{array}$ \\
\hline 6 & Power station & $\begin{array}{l}\text { Commission date } \\
\text { Turbines } \\
\text { Maximum capacity } \\
\text { Net generation } \\
\text { The right power house } \\
\text { The left power house } \\
\text { The plant load factor }\end{array}$ & $\begin{array}{l}2018 \text { (planned) } \\
16 \times 375 \text { MW Francis turbines } \\
6000 \mathrm{MW} \\
15,000 \mathrm{GWh} \text { (planned) } \\
\text { Ten } 350 \mathrm{MW} \text { Francis turbine-generators } \\
\text { Five } 350 \mathrm{MW} \text { Francis turbine-generators } \\
33 \%\end{array}$ \\
\hline 7 & Miscellaneous & $\begin{array}{l}\text { Other Use } \\
\text { Owner(s) } \\
\text { Website }\end{array}$ & $\begin{array}{l}\text { Serve as a bridge across the Blue Nile } \\
\text { Ethiopian electric power corp } \\
\text { http://www.grandmillenniumdam.net/ }\end{array}$ \\
\hline
\end{tabular}

Table 1 Grand Renaissance Dam Data 
if it in its creation phase or operation phase. Third, if its use for power generation only or it may use for irrigation purposes also. Batisha (2013) concludes that a wide spectrum of topics of landslides should be highlighted and associated with geohazards to be considered by planners, decision-makers, and concerned organizations. The International Commission on Large Dams (ICOLD) provides a forum for discussion and for the exchange of knowledge and experience in dam engineering for engineers and others concerned with the development of water resources. With a present total of 85 member countries, ICOLD leads the profession in ensuring that dams are built and operated safely, efficiently, economically, and with a minimum environmental impact (ICOLD 2014).

\section{Transboundary impact}

Elaborated under the auspices of the United Nations Economic Commission for Europe (ECE), and Adopted in 1991 and entered into force on 10 September 1997, The Convention on Environmental Impact Assessment in a Transboundary Context, the Espoo (EIA) Convention sets out the obligations of Parties to assess the environmental impact of certain activities at an early stage of planning. It also lays down the general obligation of States to notify and consult each other on all major projects under consideration that are likely to have a significant adverse environmental impact across boundaries (UNEP 2003). The Espoo (EIA) Convention had been ratified by 44 states and the European Union, until May 2013. The Espoo Convention and the Rio Declaration on Environment and Development (1992): Principle 19: States shall provide prior and timely notifcation and relevant information to potentially affected States on activities that may have a significant adverse transboundary environmental effect and shall consult with those States at an early stage and in good faith. If a planned activity (Dams and Reservoirs) is listed in Appendix 1 (Project 11) to the Convention and it is likely to cause a significant adverse transboundary impact, the EIA procedure as indicated in the Convention will have to be implemented. This procedure starts with a notification by the Party of origin to any Party that it considers to be an affected Party as early as possible and no later than when informing its own public about the proposed activity.

As defined in the Espoo Convention, "Transboundary impact" means any impact, not exclusively of a global nature, within an area under the jurisdiction of a Party caused by a proposed activity the physical origin of which is situated wholly or in part within the area under the jurisdiction of another Party. EIA of GERD project in a Transboundary Context is shown in Fig. 2.

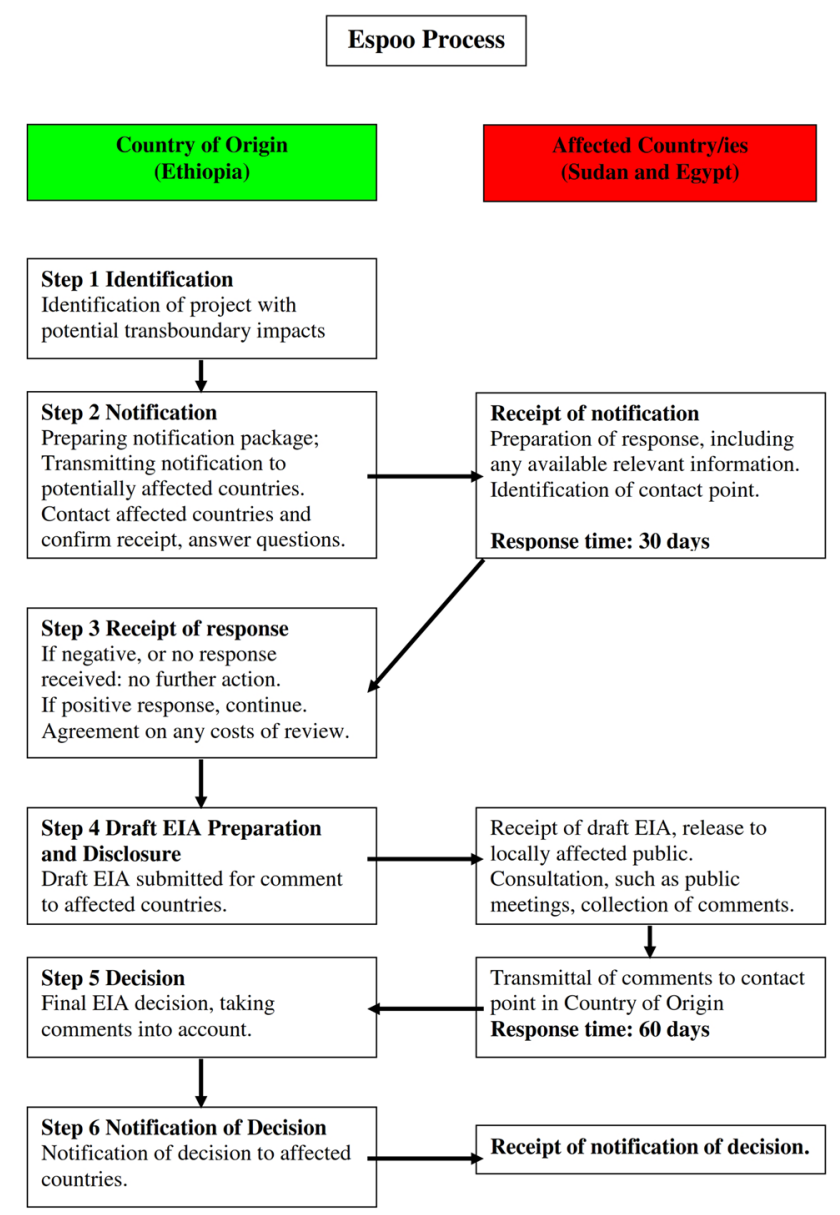

Fig. 2 EIA of GERD project in a Transboundary Context

In this study, Consolidated Environmental Impact Assessment Checklist of (Project 11-Dams and Reservoirs) as defined in Convention on Environmental Impact Assessment in a Transboundary Context is used (UNEP 2003). Significant Environmental considerations for GERD are summarized in Table 2.

\section{Methodology}

\section{Sustainability assessment technique}

Appropriate sustainability assessment technique for huge and complex projects may be best analyzed by detailed qualitative or quantitative measures requiring staff, time, and field work. Scientific theories may be incommensurable in each field of expertise in sustainability due to the overwhelming amount of information involved. Selection of appropriate sustainability assessments technique depends on numerous factors such as the type and size of the project and its alternatives, impact significance 
Table 2 Significant environmental considerations for GERD

\begin{tabular}{|c|c|}
\hline Dam project function & $\begin{array}{l}\text { Hydroelectric power source is cheap and reliable; Power generation; Water supply; Stabilize water flow/irrigation; } \\
\text { Flood prevention; Land reclamation; Navigation; Water diversion; Recreation and aquatic beauty }\end{array}$ \\
\hline \multirow{4}{*}{$\begin{array}{l}\text { Dam } \\
\text { management/operation }\end{array}$} & There are many competing stakeholders \\
\hline & Upstream and Downstream countries (if Transboundary dam impact) \\
\hline & Power generation and water supply need the reservoir to be high \\
\hline & Flood prevention needs the reservoir to be low \\
\hline Physical/chemical & $\begin{array}{l}\text { Landslides and slope stability; earthquake faults; seismic activity, due to changes in water load and/or the height of } \\
\text { the water table; reservoir silting and sedimentation; permeability of surrounding rock or soil; peak flood flows; } \\
\text { water table; river topography and dynamics; very little suspended sediment; scouring of river beds; erosion Loss of } \\
\text { riverbanks; riverline and coastal erosion; replacement of the original environment by a new inland lake; } \\
\text { suppression of the seasonal flood cycle; increased evaporation; reduction in downstream river flow; depletion of } \\
\text { groundwater aquifers; damaging the forests downstream of the dam; waterlogging; soil salinity; land/soil } \\
\text { subsidence; reduced discharge into the sea; ecology along the sea shore; disappearance of wetlands; saltwater } \\
\text { intrusion in Nile delta; climate change may causes flow shortage; reduced downstream river water quality; } \\
\text { methane emissions in tropical regions from reservoirs; increase of global warming due to changing water levels in } \\
\text { reservoir; and reservoir adds to changes in the Earth's climate }\end{array}$ \\
\hline Biological/ecological & $\begin{array}{l}\text { Fragmentation of river ecosystems; barrier between the upstream and downstream movement of river animals; } \\
\text { ecosystem damage; loss of ecospheres including endangered and undiscovered species in the area; river fisheries; } \\
\text { failure of fish breeding cycles; blocking of fish migration paths; forests and wildlife }\end{array}$ \\
\hline Sociological/cultural & $\begin{array}{l}\text { Disruption to human lives; population resettlement; compensation for flooded land; diseases; reservoir intersects the } \\
\text { migration routes of nomadic pastoralists; reservoir becomes breeding grounds for disease vectors because of slow } \\
\text { flowing water; increase the incidence of water borne diseases; loss of archeological or cultural sites underwater } \\
\text { human habitations; dam is protected by the rules of International Humanitarian Law (IHL); reduced fishing } \\
\text { opportunities; and political debate }\end{array}$ \\
\hline Economic/operational & $\begin{array}{l}\text { Hydroelectric power source should be well designed and maintained; long economic lives; flexible; low power costs; } \\
\text { elimination of the cost of fuel; no imports are needed; hydroelectric generation is vulnerable to changes in the } \\
\text { climate, rainfall, and ground and surface water levels; power availability in low-water years; removal of buildings } \\
\text { and toxic materials from the reservoir area; extensive power transmission lines are required to population centers; } \\
\text { monitoring of seepage; need routine deformation monitoring; loss of land; dam failures are catastrophic; } \\
\text { installation containing dangerous forces; massive impact of a possible destruction; water becomes scarce for } \\
\text { nomadic pastoralist; reservoir may destroy forests; flood-recession cropping; lost of cropping; methane gas } \\
\text { emissions; drainage problems in agricultural lands; reduced agricultural production; stagnant water tables; } \\
\text { drainage system is needed; pollution by agricultural chemicals; reduce the grazing opportunities for cattle; and loss } \\
\text { of land and natural resources }\end{array}$ \\
\hline
\end{tabular}

(importance; likelihood (i.e., probability, uncertainty); reversibility; timing (i.e., construction, operation, closure); duration (i.e., short, chronic, intermittent); extent of disturbance; and magnitude; and nature of impact (e.g., positive, negative, synergistic)), experience of the assessor, resources availability, public involvement and procedural or administrative requirements.

The key in qualitative technique is to use logic that can produce reproducible and relatively consistent results based on professional judgment. The main features of qualitative technique are: use qualitative data (words); naturalistic inquiry; holistic, system-wide perspective; uniqueness and diversity; inductive reasoning; purposeful sampling; emergent; flexible design; content analysis; extrapolations; relatively, decision process is simple, easy and fast; easy to communicate; selection of scenarios is often tacit or implicit; may give a wrong impression of precision and safety; expensive for society ("worst case" scenarios leads to conservative results); may "neglect" less severe scenarios in risk control and safety management.
The main features of quantitative technique are: use quantitative data (numbers); scientific/experimental design; independent; dependent variables, standardized, uniform, deductive reasoning; probabilistic, random sampling, fixed, controlled design; statistical analysis; generalizations; complete analysis; opportunity for setting priorities; focus on most "risky" items; transparent, both probabilities and consequences are included explicitly; results can easily be compared; not sensitive for selection of scenarios; structured, standardized; expensive and cumbersome analysis, which requires expert knowledge; the "probabilistic" element in the result is hard to communicate; result suggests large accuracy, but it includes large uncertainty; and quantitative techniques may require extensive data gathering efforts.

There are many factors that may necessitate using the qualitative technique: the lack and/or inadequacy of baseline data, the time frame provided for data acquisition and analysis, the terms of reference provided for the sustainability assessment, and the capacity of the assessors to 
cover a wide range of issues. Reliable quantitative information on climate conditions, water, topography, soil erosion process and deforestation is not available. Huge quantities of data in Dams and Reservoirs Projects and/or cases where the database is poor can be processed. Even where quantitative environmental data is available, the overall use of this data requires a subjective judgment of the possible impact, its spatial scale and potential magnitude.

Qualitative mapping of sustainability assessments aims to better realization of possible impacts of the project on the environment, society and economy. The qualitative mapping assesses the impacts against the baseline in qualitative terms; consider the risks and uncertainties of the project; and decide if sustainability assessment requires a quantitative measurement. Qualitative mapping may be supported by available quantitative data.

A qualitative technique incorporates expertise, people, projects, communities, challenges, studies, inquiry, and research areas that are strongly associated with a given project. Qualitative assessment can offer a valuable contribution to the knowledge base and include functionality, utility, feasibility, efficiency, propriety and accuracy. Culturally appropriate should respect such characteristics as culture differences; organizational affiliation; nationality; religion; language; ethnicity; gender; abilities; physical characteristics; class; and economic status.

Involving leading experts if possible, qualitative assessment should verify both significant and uncertainty about impacts caused by the project. Based on the analysis, the decision can be taken to perform a dedicated ex-post quantitative assessment. In case of development projects where data may be scarce and implementation may take a number of years, it is necessary to ensure some degree of transparency and objectivity in the qualitative assessment and evaluation of the impacts. With the passage of time, sustainability assessment needs to be re-assessed and the data should be open to scrutiny and revision, as new data becomes available.

\section{Sustainability assessment in transboundary context}

Sustainability Assessment is not an exact science and it is risky to act as if it is. The use of a combination of different-quantitative and qualitative-techniques can highlight different dimensions of impact. The prerequisite for the sustainability assessment is the knowledge and the availability of information and data. Challenges in attaining sustainability involve high uncertainty (has to judge numerous years into future); complexity (especially, to gather information that can be analyzed and presented in a way that will be credible and useful); requires multi-disciplinary approach; many, interrelated factors, resources availability (time, money, and staff); data reliability and validity; cultural appropriateness; and evidence credibility.

Sustainability assessment in transboundary context is a study of political, economic, ecological and cultural relations and processes. It is an interdisciplinary field which systematically studies human interaction with the environment in the interests of solving complex problems. Giving fair (not equal) weight to each perspective, it is a broad field of study that includes also the natural environment, built environment, and the sets of relationships between them. It implies a future development strategy that crosses many disciplinary boundaries to create a holistic approach based on problem-solving process. It is strongly associated with disciplinary knowledge and integrates aspects from multiple disciplines, therefore addressing any problems that may arise from narrow concentration within specialized fields. Sustainability assessment should ensure access to diverse evidence, interdisciplinary expertise and sufficient time for reflection and exploration. Its holistic approach increases its complexity.

Sustainability assessment may be based on both qualitative and quantitative evidence to minimize future causalities. Ideally, sustainability assessment in transboundary context report should comprise a series of documents providing a detailed valuation against the baseline in quantitative and monetary terms, wherever possible (e.g. depending on the timing, budget, type of data needed and new knowledge generated by a research activity), and in qualitative terms of the likely impacts and/or benefits of the development project. In transboundary context, sustainability assessment should be made in quantitative terms as far as possible. For example, impact prediction; receivers, habitats or resources which are vulnerable to change; extent and magnitude of the anticipated changes and effects; project and environment interactions; chain of events or "pathways" linking cause with effect; harmful or beneficial to the environment; reasonable case scenario and/or the worst case scenario should be acceptable by every State. Some of the qualitative indicators takes a life cycle perspective and thus may vary from one country to another.

The assessor is constrained by a lack of time (for detailed quantitative data collection and analysis) and by an uncertainty of the probable changes and effects. Assessors should not use in-depth knowledge, know-how and specialized scientific languages of the scientific disciplines involved but skills in moderation, mediation, and knowledge transfer. The panel of assessors is made up of people from multiple disciplines and professions. The panel is more holistic and seeks to relate all disciplines into a coherent whole. The assessors act as equal stakeholders in addressing a common challenge. The lack of shared vocabulary between assessors may be a problem. The 
science disciplines included: physics, chemistry, biology, and geology. The social science disciplines included: sociology, economics, and politics.

\section{The rapid impact assessment matrix (RIAM)}

The RIAM technique is a standard definition of the assessment criteria and the process by which semi-quantitative values for all of these criteria can be assembled to produce an accurate and independent score for each state. RIAM describes a system of scoring has been designed to allow subjective judgments to be quantitatively assessed. RIAM is appropriate to Sustainability Assessment where a multidisciplinary approach is applied. RIAM offers a practical tool for illustrating and analysing impact pathways.

RIAM allows scoring based on multiple criteria. Both quantitative and qualitative data may be assessed by means of RIAM's scales. Recently, many researchers have discussed RIAM technique and some of them have highlighted quantitative and/or qualitative techniques. The RIAM technique is a semi-quantitative technique that uses a standard definition of the important assessment criteria, and which consequently provides for an accurate and independent score for each condition (Pastakia and Jensen 1998). Qualitative techniques are used because they are versatile in environmental impact assessment Toroa et al. (2013). RIAM minimizes the elements of subjectivity and introduces some degree of transparency and objectivity Taheri et al. (2014). RIAM methodology is more suitably applied when decision-making schedules are tight, data are too scarce to carry out a comprehensive quantitative evaluation, trans-boundary issues are involved, or a combination of the three pertains Li et al. (2014). Environmental score under RIAM analysis helps as decision supporting tool. RIAM can be a reliable tool to identify the suitability of the site in accordance with ecological, physical, biological, social/cultural and economic quality of the project Suthar and Sajwan (2014). RIAM can be a technique for easy assessing and comparison of the various kinds of projects Shakib-Manesh et al. (2014). RIAM has the ability to make use of the results of different types of environmental assessment and to make uncertainty and lack of knowledge explicit. The non-specialist knowledge users are both guided and made aware of differing scientific and stakeholder opinion by means of RIAM Upham and Smith (2014a, b). In the United Kingdom, a proposed onshore wind farm has been evaluated quantitatively at the construction and operation stages using RIAM Phillips (2015).

Assessment criteria are defined to be affected by change rather than be related to individual projects for both groups. Five criteria have been developed to use in the RIAM represent the most important fundamental assessment conditions for all EIAs. These criteria satisfy the two main principles. The first is generality of the criterion, to allow it to be used in different EIAs. The second is the valuation of the criterion to determine whether it be treated as a Group (A) or Group (B) condition. The ruling of each Group criteria and scales are shown in Table 3.

Table 3 Definition of assessment criteria

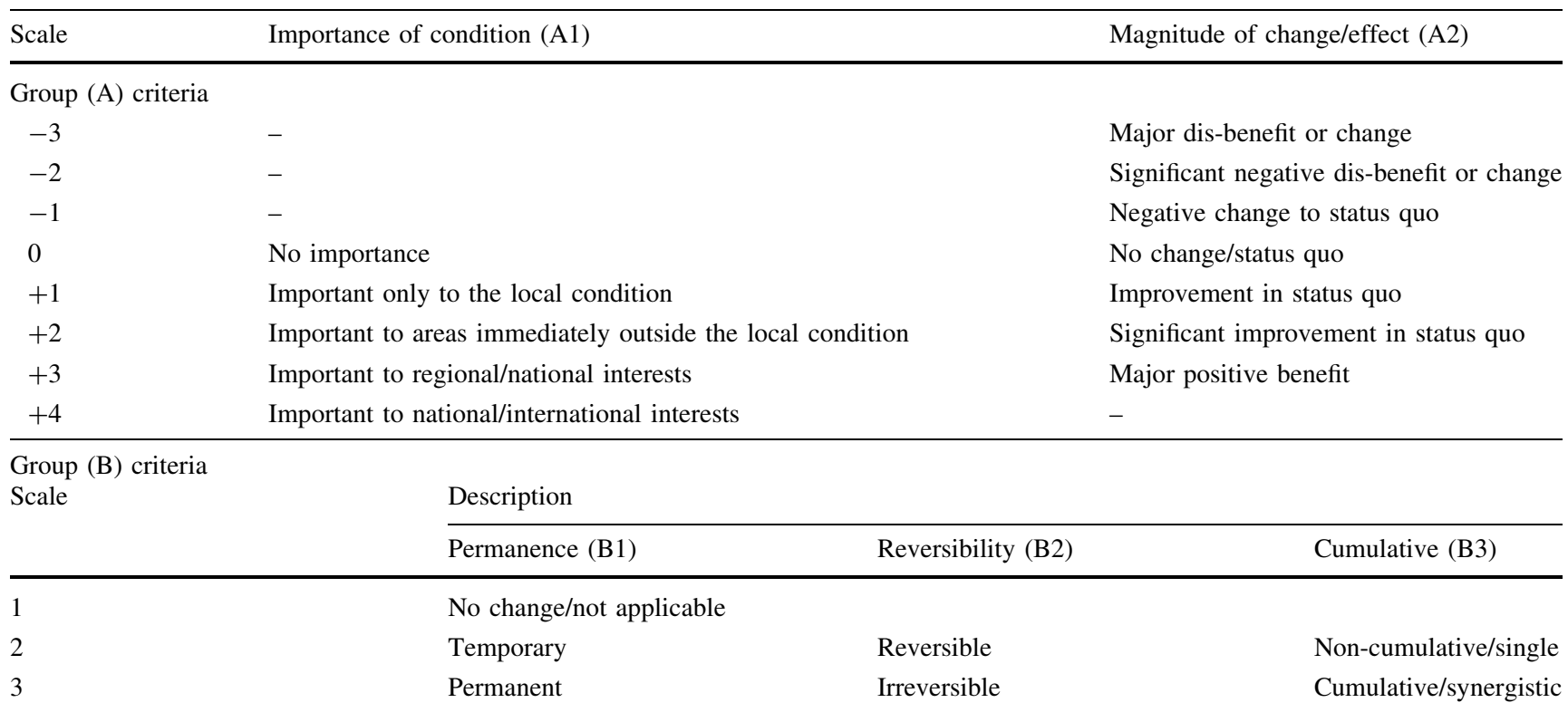




\section{Environmental components}

The RIAM requires specific assessment components to be defined through a process of scoping. The environmental components (shown in Tables 4, 5, 6, 7) fall into one of four categories, which are defined as follows:

\section{Results}

Application of Consolidated Environmental Impact Assessment Checklist (Project 11-Dams and Reservoirs) to score Grand Ethiopian Renaissance Dam (GERD) environmentally, according to Convention on Environmental Impact Assessment in a Transboundary Context, United Nations Economic Commission for Europe is presented in Appendix 1. Physical and Chemical Components such as Air, Water, Climate, Soil and Landscape, and Biological and Ecological Components will affect both Flora and Fauna, mainly due to reservoir formation and changes in water system. Economic and Operational Components such as present and potential use of natural resources, employment opportunity and economic development, Also, Quality of life in Social and Cultural
Components maybe seriously affected among upstream and downstream countries. Environmental situation of Grand Ethiopian Renaissance Dam GERD has been assessed using RIAM. There will be changes in the natural state ("status quo") in the 4 analyzed environmental categories. The summary of the total environmental assessment are given (Appendix 2). Although, there may be positive socioeconomic changes in US country, there are many negative impacts in DS countries. From environmental point of view, the RIAM results can be used to demonstrate that there are many negative impacts that have destructive environmental effect.

The RIAM results show a largely negative series of impacts; the range bands used indicate that these are generally serious; falling mainly in the bands of major negative change/impact. In this study the ranges were not expressed as \pm 5 , but as $\pm \mathrm{A}$ to $\mathrm{E}$ (with ' $\mathrm{N}$ ' representing the zero range). The use of letters may be useful in avoiding confusion between ES values and range numbers. Figure 3 shows the comparison of RIAM results for US country and DS countries. The histograms provide comparative products of positive/negative impacts concerning quality of life between US country and DS countries. Identifying important negative components, more accurate environmental

Table 4 Definition of environmental components

\begin{tabular}{ll}
\hline Category & Description \\
\hline Physical/chemical & $\begin{array}{c}\text { Covering all physical and chemical aspects of the environment, including natural resources, and degradation of the } \\
\text { physical environment by pollution }\end{array}$ \\
Biological/ecological & $\begin{array}{l}\text { Covering all biological aspects of the environment, including renewable natural resources, conservation of biodiversity, } \\
\text { species interactions, and pollution of the biosphere } \\
\text { Covering all human aspects of the environment, including social issues affecting individuals and communities; together } \\
\text { with cultural aspects, including conservation of heritage, and human development }\end{array}$ \\
Economic/operational & $\begin{array}{r}\text { To qualitatively identify the economic consequences of environmental change, both temporary and permanent, as well } \\
\text { as the complexities of project management within the context of the project activities }\end{array}$ \\
\hline
\end{tabular}

Table 5 Range bands used for RIAM

\begin{tabular}{lllcl}
\hline & \multirow{2}{*}{ RIAM Environmental score (ES) } & \multicolumn{2}{l}{ Range value (RV) } & Description of range band \\
\cline { 3 - 4 } & & Alphabetic & Numeric & \\
\hline 1 & 72 to 108 & E & 5 & Major positive change/impact \\
2 & 36 to 71 & D & 4 & Significant positive change/impact \\
3 & 19 to 35 & C & 3 & Moderate positive change/impact \\
4 & 10 to 18 & B & 2 & Positive change/impact \\
5 & 1 to 9 & A & 1 & Slight positive change/impact \\
6 & 0 & N & 0 & No change/status quo/not applicable \\
7 & -1 to -9 & - A & -1 & Slight negative change/impact \\
8 & -10 to -18 & - B & -2 & Negative change/impact \\
9 & -19 to -35 & - C & -3 & Moderate negative change/impact \\
10 & -36 to -71 & - D & -4 & Significant negative change/impact \\
11 & -72 to -108 & - E & -5 & Major negative change/impact \\
\hline
\end{tabular}


Table 6 RIAM results for the GERD project (Ethiopia)

\begin{tabular}{|c|c|c|c|c|c|c|c|}
\hline & \multirow[t]{2}{*}{ RIAM Environmental score (ES) } & \multicolumn{4}{|l|}{ Components } & \multirow[t]{2}{*}{ Total } & \multirow[t]{2}{*}{ Class } \\
\hline & & Physical/chemical & Biological/ecological & Social/cultural & Economic/operational & & \\
\hline 1 & 72 to 108 & 0 & 0 & 6 & 4 & 10 & $\mathrm{E}$ \\
\hline 2 & 36 to 71 & 0 & 0 & 0 & 0 & 0 & $\mathrm{D}$ \\
\hline 3 & 19 to 35 & 0 & 0 & 0 & 0 & 0 & $\mathrm{C}$ \\
\hline 4 & 10 to 18 & 0 & 0 & 0 & 0 & 0 & $\mathrm{~B}$ \\
\hline 5 & 1 to 9 & 0 & 0 & 0 & 0 & 0 & A \\
\hline 6 & 0 & 0 & 0 & 0 & 0 & 0 & $\mathrm{~N}$ \\
\hline 7 & -1 to -9 & 3 & 0 & 0 & 0 & 3 & $-\mathrm{A}$ \\
\hline 8 & -10 to -18 & 1 & 0 & 1 & 0 & 2 & $-\mathrm{B}$ \\
\hline 9 & -19 to -35 & 0 & 0 & 3 & 0 & 3 & $-\mathrm{C}$ \\
\hline 10 & -36 to -71 & 6 & 8 & 1 & 0 & 15 & $-\mathrm{D}$ \\
\hline 11 & -72 to -108 & 20 & 9 & 2 & 0 & 31 & $-\mathrm{E}$ \\
\hline
\end{tabular}

Table 7 RIAM results for the GERD project (Sudan \& Egypt)

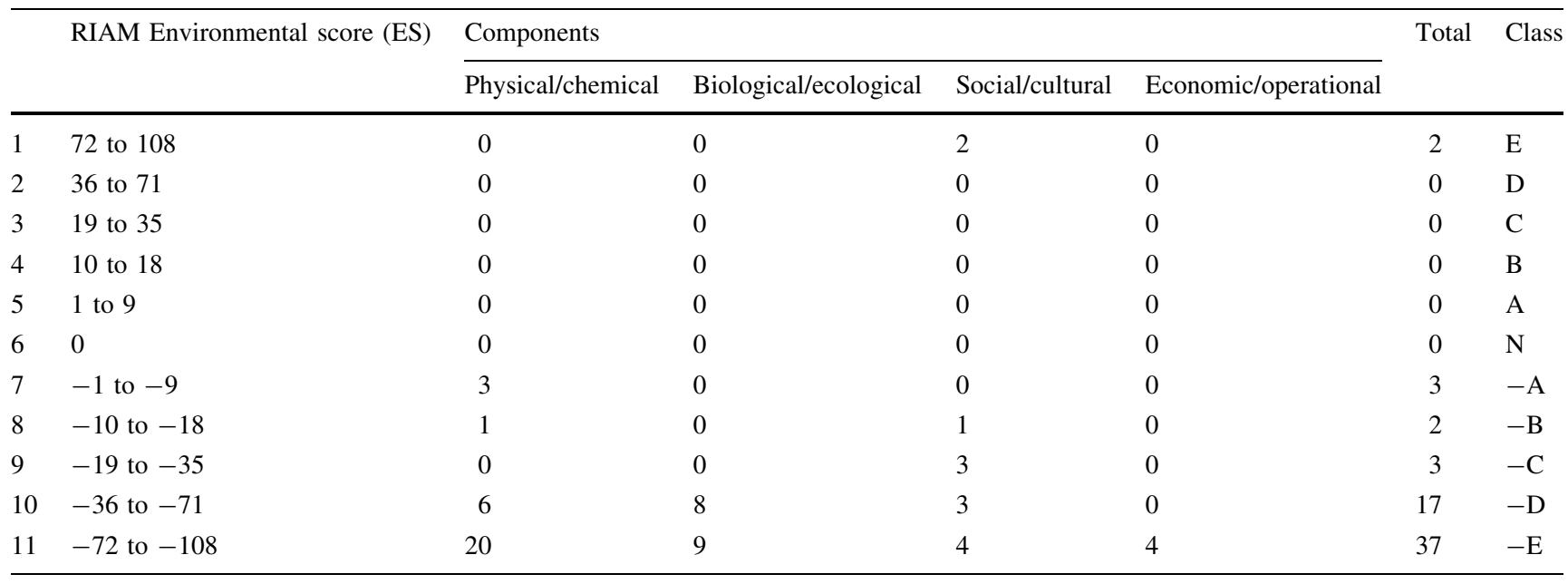

study or mitigation may be required. The RIAM results are able to identify areas where more environmental data is needed. So, perfect investigations may be carried out, without unnecessary delays in the GERD planning/project cycle.

In Physical and Chemical category, Air, Water, Climate, Soil and Landscape have been analyzed: geophysicists, ground, water quality and hydraulic resources, climate, air quality and the sonorous environment. RIAM indicates that in this category and in this phase there are three types of impacts, being, however, all of them negative: reduced negative impacts for the sonorous environment parameters, air quality and climate; less negative impacts for the hydraulic parameters and geophysical quality of the water and resources; moderately negative ground impacts. Factors such as odour; noise; vibration; heavy metals; mercury; arsenic; selenium; vanadium; Beryllium; faecal coliforms; nutrients; biological oxygen demand; chemical oxygen demand; total organic carbon; dissolved oxygen; inundation of lands; basin hydraulic loss; streamflow variation; changes to estuaries; sedimentation; scouring; turbidity; change in $\mathrm{pH}$; changes in surface water temperature; changes in humidity; shoreline erosion; land use changes; visual aspects; physical composition; and impact on sensitive lands are environmentally assessed.

In Biological and Ecological category, the Flora and Fauna factors have been analyzed: flora, vegetation, fauna and habitats. The RIAM indicates that there are two types of impacts: less negative impacts for fauna and habitats and moderately negative impacts for flora and vegetation. Mainly, reservoir creating and changes in water system will affect Flora factors and cause changes in natural vegetation; disturbance of aquatic habitat; disturbance of plant habitat; disturbance of natural vegetation; decrease in biodiversity; impact of threatened species; changes in species population; changes in aquatic food web; changes in mammal food web and impact on protected areas. Fauna factors such as migratory changes for fish and mammals; disturbance of 


\section{Upstream countries}
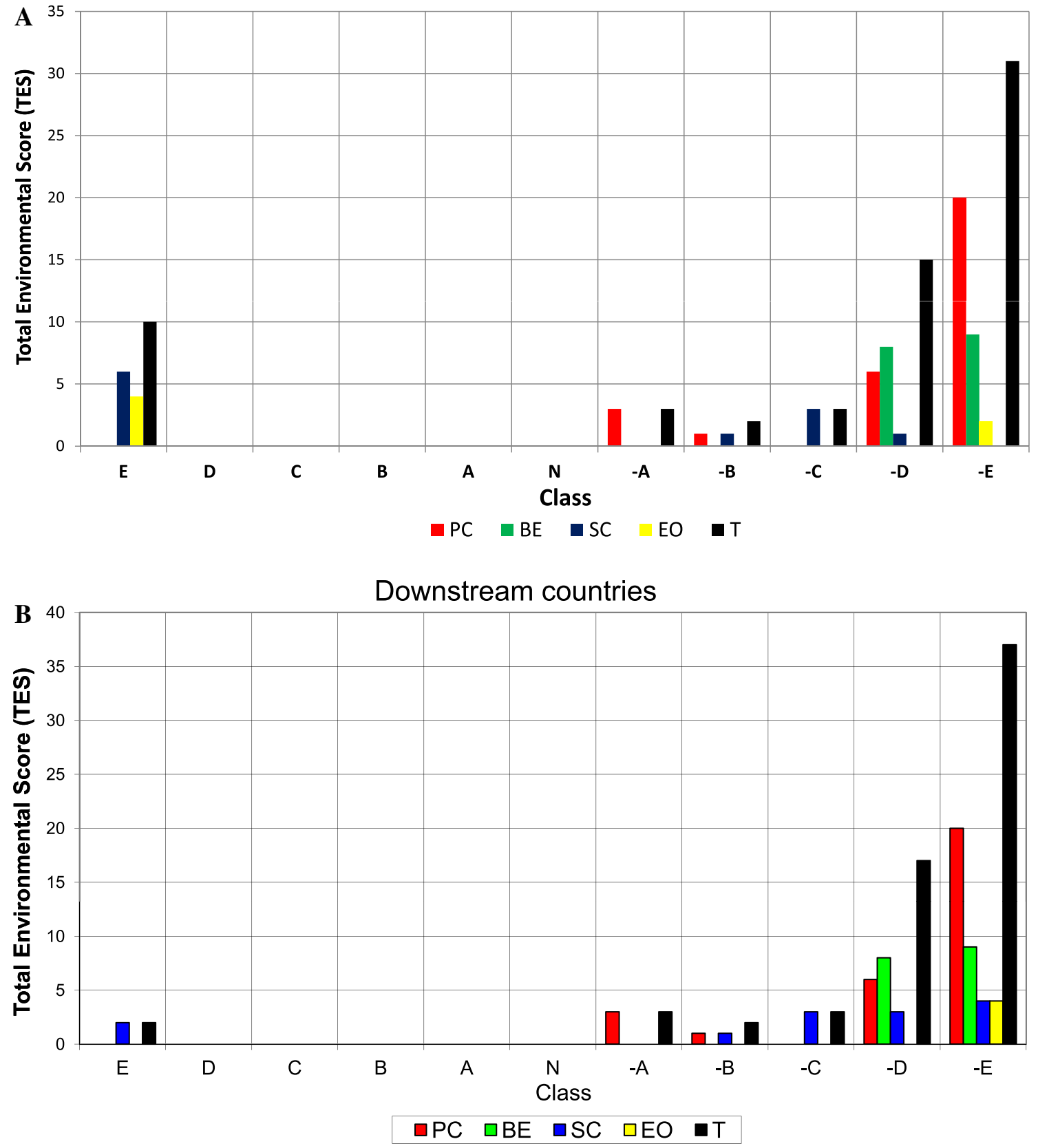

Fig. 3 a RIAM results for the GERD project (Upstream countries). b RIAM results for the GERD project (Downstream countries)

wildlife habitat; decrease in biodiversity; impact on threatened species; changes in species population and changes in mammal food web will also be affected.

In Sociological and Cultural category, the Historical Monuments; Cultural Heritage; Human Health and Safety and Quality of Life parameters factors have been analyzed: social-economic, landscape, patrimony and areas with specific regulations. The RIAM indicates that in this category and this phase there are three types of impacts, being, however, all of them negative: reduced negative impacts for the social-economic parameters and areas with specific regulations; less negative impacts for the landscape; moderately negative impacts for the patrimony. Factors such as historical sites; archaeological changes; palaeontological changes; cultural changes; land use changes; way of life; changes in disease incidence; increase in parasitic disease; risk of surface water contamination; changes to well being of life; changes to quality of life; quality of recreational 
facilities; and quantity of recreational facilities are environmentally assessed.

In Economic and Operational category, the RIAM analyzed the Natural Resources, Employment and Economic Development parameters both upstream and downstream countries. The RIAM indicates that the present and potential use of natural resources, employment opportunity and economic development factors will have major positive change/impact for upstream countries where as cause major negative change/impact for downstream countries.

\section{Discussion}

Knowing that qualitative technique may be biased according to the interests, experience or knowledge of the evaluator, RIAM can be classified as a semi-qualitative or semi-quantitative technique because assessment of impacts made by assessors is produced in the light of both quantitative rules and computerized matrix system not only subjective judgments. RIAM is an acceptable and accurate technique to identify the sustainability of transboundary projects based on interdisciplinary perspective. RIAM technique is a matrix system that employs quantitative scores based on ranking criteria. RIAM is suitable for sustainability assessment in transboundary context in which a multi-disciplinary approach is used because it allows for data from different components and perspectives to be evaluated simultaneously.

Bruch et al. (2008) have summarized lessons learned in pilot-testing a methodology to assess the accuracy of Transboundary impact assessments (TIAs). They asked if the country of origin considers that a transboundary impact assessment is not necessary, can one be requested or demanded by a potentially affected country, or by members of the public in the potentially affected country. They highlighted some important issues such as the disappearance of local knowledge, scant public involvement contributed to the assessment's shortcomings, particularly with regard to resettlement. The environmental impact assessment failed to recognize that people living downstream might suffer as much or more harm than those living close to the site. It can be challenging, if not legally and politically problematic, for a project proponent in one country to collect data in another country. This is particularly true for resources such as water, whose use can be especially politically sensitive. While politicization of transboundary impact assessment decision-making processes happens in both domestic and transboundary contexts, TIA can become much more complicated and politicized because two or more sovereign powers are involved. The process of conducting a transboundary impact assessment can improve institutional coordination and collaboration among government institutions, as well as between governmental and non-governmental actors. Transboundary impact assessment methodologies seem to under-predict the severity of actual impacts: there was not a single instance identified where a TIA over-estimated an impact. This was particularly true for social impacts. Kim et al. (2013) illustrated that it is especially difficult to examine impacts on multiple (e.g., regional and local) scales in detail.

The overall goal of this article is to develop a methodology for identifying specific environmental risk factors associated with people's vulnerability due to the project that could be used to more effectively target and implement adaptation responses and interventions, based on tranboundary water basins. The approach developed is definitely transferable to other regions, easily updatable, and adaptable to a variety of population, exposure, and environment outcome scenarios. The approach calls for integrating population vulnerability and environmental exposure data in order to facilitate fine-scale assessment of the project risks and inform targeted interventions. The significant tranboundary impacts associated with the project, particularly among vulnerable groups such as children and women, who are especially endangered by degraded life quality, should be assessed.

Transboundary water basins may be an important economic infrastructure for goods movement, tourism, and commerce. Focused on environmental impacts of the project, the stakeholders with their scientists, health advocates, government agencies, planners, policymakers, and affected community members can highlight the environmental, social and economic burden posed by the project, and discuss gaps, needs, and recommendations for action towards effective transboundary water resources management.

The lack of commitment with the existing treaties, flexibility of the existing international agreements, or appropriate international mechanisms of transboundary collaboration, maybe the key factors which have promoted and accelerated the application of RIAM technique at the transboundary water basins in the world. The purpose of the Article is to convene regional stakeholders to exchange information about agency activities and policies relevant to the challenges of the transboundary watershed and to discuss opportunities to resolve specific transboundary watershed issues including urban rivers and river restoration, land use and sedimentation, and the risks of both global and climate change. Background information should be also presented on the changing land use and sedimentation in the watershed and the other challenges to policy makers, researchers, and community members. Particularly 
in tranboundary context, the subjective assessments may create legal uncertainty regarding what would be the applicable compensation mechanism, in case the solution proposed and implemented is failing. The main problem is that such subjective assessments might generate unexpected consequences. The stakeholders seem satisfy with the performance of the RIAM technique regarding the flexibility and creativity in the solutions implemented directly to the main environmental issues.

EIA has suffered from the subjective assessments facing to criticism for its lack of transparency. It is obligatory to ensure sufficient degree of transparency and objectivity in the qualitative environmental assessment of transboundary impact projects (in particular shared natural resources projects where data may be scarce and implementation may take a number of years). To overcome these drawbacks in EIA process, the Rapid Impact Assessment Matrix (RIAM) has been used. Implementation of RIAM requires involvement of the public and officials of both the affected countries and countries of origin. Complex process of technical and participatory assessment of transboundary impacts is expected. Setting standards, contacts and timelines between the involved parties is obligatory. National legislation and administrative measures may be adopted or modified. Environmental values and significant impacts should be homogenous in all countries. Preliminary consultations between developer, countries of origin and affected countries may be considered as the acceptable starting point. Establishment of "Joint Multilateral Body" for conducting transboundary evaluation of the project and EIA processes may be a good practice to facilitate application of RIAM. Public participation must take place simultaneously with the decision making process in all involved countries. An agreement on tasks and the shared costs implied should be reached. Joint public hearings should be supported. Publicity in mass media and/ or translations may be required. The public should have the opportunity to comment on the EIA programme and EIA report. Common agreement on how public comments and/ or objections are received, evaluated and presented in the EIA documentation is mandatory. EIA report should include the results of the multilateral evaluation and of the public participation. Credibility and technical accuracy of the EIA report should be agreed and legally binding. Similar Different decision making process will be helpful, in particular, strict enforcement of the rules and regulations, tradition, guidelines, agreed evaluation criteria and agreement on alternative solutions. Licensing process may include some phases such as the "decision in principle", ratification of the decision in principle by Parliament, issue of the construction license and issue of the operating license.
RIAM technique may be a tool for enhancing benefits and reducing costs by establishing agreements with neighbouring States. The results shown in this paper suggest that RIAM technique is working relatively well in case of the lack of appropriate international mechanisms of transboundary collaboration, compared with informal rules at the shared water resources regions. According to the case study presented in this paper, the implementation of RIAM technique may be more preferable by the population in the transboundary water basins than both indefinite and informal rules. The perceptions toward the risks of global climate change causing more frequent or severe negative effects or impacts play an important role in the way the public perceives the overall issue, supports relevant policies, and commits to necessary behavioral changes. The role of trust is an important aspect that influences the success of policies targeting global climate change as well as the public's willingness to commit to behavioral changes.

In Tranboundary context, the RIAM technique should be conducted by an interdisciplinary team from all stakeholders to prevent environmental damage before it occurs. The RIAM technique may be conducted in many interlinked phases involve constructing a novel tranboundary knowledge-base of socio-economic and hazard exposure measures, and pioneering methods for mapping environmental vulnerability, hazard exposure, and risk in order to identify areas of greatest environmental vulnerability to the project. By using the constructed knowledge-base, RIAM can test the environmental damage by analyzing associations between environmental vulnerability and hazard exposure variables, in order to determine whether or not particular social groups are exposed to the project-related hazards. The analyses may be extends from cross- sectional to a longitudinal approach to analyze how changes in environmental indicators are related to changing patterns due to the project.

The significance of the results of this work may be discussed based on significant environmental impacts of the project for both upstream and downstream countries. An example for Significant Environmental considerations for Grand Ethiopian Renaissance Dam GERD is summarized in Table 2. Based on definition of Assessment Criteria, Environmental Components and Range bands, Rapid Impact Assessment Matrix RIAM can identify the impacts. Focusing on a wider cultural area, increased complexity of the EIA process with new stages and new participants and additional administrative procedures, costs and time taken for the decision making process should be predicted. There are no limitations to RIAM in identifying transboundary impacts, if required data and information are available. 
The hope is that they will be able to agree on a number of conclusions and actions to achieve physical and social drivers of water sustainability. These may include: sustainable water management of the transboundary Watershed is a priority. Tranboundary watershed planning and management should be initiated through convening of a transboundary watershed different stakeholders. The challenges of the transboundary watershed need to dedicate sustainable natural and water resources to that end. The stakeholders should regularly interact with their counterparts across the border as well as with other national and local agencies working in the watershed. All barriers should be addressed by all stakeholders involved in transboundary efforts.

\section{Conclusions}

The Nile Basin countries should use shared water resource in a sustainable manner. So, the improvement of the EIA practice is effective. Grand Ethiopian Renaissance Dam GERD is environmentally analyzed based on the Convention on Environmental Impact Assessment in a Transboundary Context, Espoo Convention that Elaborated under the auspices of the United Nations Economic Commission for Europe. Using Rapid Impact Assessment Matrix RIAM technique, Environmental Impact of Grand Ethiopian Renaissance Dam GERD is assessed in transboundary context. RIAM is an effective technique in environmental impact assessment, in particular with very complicated transboundary context as verified in this study. RIAM indicates that in both Physical and Chemical category and Biological and Ecological category, there are major negative impacts for both upstream and downstream countries. On the other hand, the RIAM indicates that in Sociological and Cultural category and Economic and Operational category will have a positive impact in upstream countries and negative impacts in downstream countries. The study concludes RIAM is a useful tool for decision makers as it is able to display the results of different development scenarios and produce transparent environmental solutions, even with very complex options. Huge quantities of data in Dams and Reservoirs Projects and/or cases where the database is poor (for whatever reason) can also be processed as illustrated.

Given the complexity of the transboundary context, qualitative techniques are valid. It is better to have a holistic qualitative overview than a limited quantitative assessment. Because its ability to transparently produce numerous and dissimilar results, RIAM has a good potential in both policy deliberation and sustainability studies. To render them useful for policy purposes, sustainability assessment should be strived for the clear, reliable, accurate and certain results. Finally, it is hoped that the realistic ability of RIAM in dealing with transboundary context is paved the way to full approval of both upstream and downstream countries in achieving sustainable development for shared water resources.

\section{Appendix 1}

Application of Consolidated Environmental Impact Assessment Checklist (Project 11-Dams and Reservoirs) to score Grand Ethiopian Renaissance Dam (GERD) environmentally, according to Convention on Environmental Impact Assessment in a Transboundary Context, United Nations Economic Commission for Europe.

\begin{tabular}{|c|c|c|c|}
\hline ID & Category & Factor & Comments \\
\hline \multicolumn{4}{|c|}{ Physical/chemical components } \\
\hline $\mathrm{P} / \mathrm{C} 1$ & Air & Odour & \multirow[t]{3}{*}{ Human health } \\
\hline $\mathrm{P} / \mathrm{C} 2$ & & Noise & \\
\hline $\mathrm{P} / \mathrm{C} 3$ & & Vibration & \\
\hline $\mathrm{P} / \mathrm{C} 4$ & \multirow[t]{6}{*}{ Water } & Heavy metals: & \multirow{6}{*}{$\begin{array}{l}\text { Molecular bonding in soils, } \\
\text { reference } 2 \text {, human health, } \\
\text { flora, fauna, aquatic life }\end{array}$} \\
\hline $\mathrm{P} / \mathrm{C} 5$ & & Mercury (Hg) & \\
\hline P/C 6 & & Arsenic (As) & \\
\hline $\mathrm{P} / \mathrm{C} 7$ & & Selenium (Se) & \\
\hline $\mathrm{P} / \mathrm{C} 8$ & & $\begin{array}{l}\text { Vanadium } \\
\text { (Vn) }\end{array}$ & \\
\hline $\mathrm{P} / \mathrm{C} 9$ & & $\begin{array}{l}\text { Beryllium } \\
\quad(\mathrm{Be})\end{array}$ & \\
\hline $\mathrm{P} / \mathrm{C} 10$ & & $\begin{array}{l}\text { Faecal } \\
\quad \text { coliforms }\end{array}$ & $\begin{array}{l}\text { Water quality, aquatic life, } \\
\text { human health }\end{array}$ \\
\hline $\mathrm{P} / \mathrm{C} 11$ & & Nutrients & \multirow[t]{5}{*}{ Water quality, aquatic life } \\
\hline $\mathrm{P} / \mathrm{C} 12$ & & $\begin{array}{l}\text { Biological } \\
\text { oxygen } \\
\text { demand } \\
\text { (BOD) }\end{array}$ & \\
\hline $\mathrm{P} / \mathrm{C} 13$ & & $\begin{array}{l}\text { Chemical } \\
\text { oxygen } \\
\text { demand } \\
\text { (COD) }\end{array}$ & \\
\hline $\mathrm{P} / \mathrm{C} 14$ & & $\begin{array}{l}\text { Total organic } \\
\text { carbon } \\
\text { (TOC) }\end{array}$ & \\
\hline $\mathrm{P} / \mathrm{C} 15$ & & $\begin{array}{c}\text { Dissolved } \\
\text { oxygen }\end{array}$ & \\
\hline $\mathrm{P} / \mathrm{C} 16$ & & $\begin{array}{l}\text { Inundation of } \\
\text { lands }\end{array}$ & $\begin{array}{l}\text { Landscape, flora, fauna, soil, } \\
\text { socio-economic }\end{array}$ \\
\hline $\mathrm{P} / \mathrm{C} 17$ & & $\begin{array}{l}\text { Basin } \\
\text { hydraulic } \\
\text { loss }\end{array}$ & Aquatic life, landscape, soil \\
\hline $\mathrm{P} / \mathrm{C} 18$ & & $\begin{array}{l}\text { Streamflow } \\
\text { variation }\end{array}$ & $\begin{array}{l}\text { Aquatic life, landscape, } \\
\text { erosion/sedimentation, } \\
\text { flora, fauna }\end{array}$ \\
\hline $\mathrm{P} / \mathrm{C} 19$ & & $\begin{array}{r}\text { Changes to } \\
\text { estuaries }\end{array}$ & $\begin{array}{l}\text { Aquatic life, flora, fauna, } \\
\text { landscape, erosion }\end{array}$ \\
\hline P/C 20 & & Sedimentation & Aquatic life, water quality \\
\hline
\end{tabular}




\begin{tabular}{llll}
\hline ID & Category & Factor & Comments \\
\hline P/C 21 & & Scouring & Aquatic life \\
P/C 22 & & Turbidity & Aquatic life, water \\
P/C 23 & & Change in pH & \\
P/C 24 & Climate & Changes in & \\
& & surface water & \\
& & temperature & \\
P/C 25 & & Changes in & humidity \\
& & Shoreline & Changes in water \\
P/C 26 & Soil & erosion & system \\
& & Land use changes & \\
P/C 27 & Landscape & Visual aspects \\
P/C 28 & & Physical & \\
P/C 29 & & composition & \\
& & Impact on & \\
P/C 30 & & sensitive & lands \\
& &
\end{tabular}

\begin{tabular}{|c|c|c|c|}
\hline ID & Category & Factor & Comments \\
\hline \multicolumn{4}{|c|}{ Biological/ecological components } \\
\hline $\mathrm{B} / \mathrm{E} 1$ & Flora & Changes in natural vegetation & \multirow{10}{*}{$\begin{array}{l}\text { Reservoir, } \\
\text { changes in } \\
\text { water } \\
\text { system }\end{array}$} \\
\hline $\mathrm{B} / \mathrm{E} 2$ & & Disturbance of aquatic habitat & \\
\hline B/E 3 & & Disturbance of plant habitat & \\
\hline $\mathrm{B} / \mathrm{E} 4$ & & $\begin{array}{l}\text { Disturbance of natural } \\
\text { vegetation }\end{array}$ & \\
\hline B/E 5 & & Decrease in biodiversity & \\
\hline $\mathrm{B} / \mathrm{E} 6$ & & Impact of threatened species & \\
\hline B/E 7 & & Changes in species population & \\
\hline $\mathrm{B} / \mathrm{E} 8$ & & Changes in aquatic food web & \\
\hline B/E 9 & & Changes in mammal food web & \\
\hline $\mathrm{B} / \mathrm{E} 10$ & & Impact on protected areas & \\
\hline B/E 11 & \multirow[t]{7}{*}{ Fauna } & Migratory changes-fish & \multirow{7}{*}{$\begin{array}{l}\text { Reservoir, } \\
\text { changes in } \\
\text { water } \\
\text { system }\end{array}$} \\
\hline $\mathrm{B} / \mathrm{E} 12$ & & Migratory changes-mammals & \\
\hline B/E 13 & & Disturbance of wildlife habitat & \\
\hline B/E 14 & & Decrease in biodiversity & \\
\hline B/E 15 & & Impact on threatened species & \\
\hline B/E 16 & & Changes in species population & \\
\hline B/E 17 & & Changes in mammal food web & \\
\hline
\end{tabular}

\begin{tabular}{|c|c|c|c|}
\hline ID & Category & Factor & Comments \\
\hline \multicolumn{4}{|c|}{ Social/cultural components } \\
\hline $\mathrm{S} / \mathrm{C} 1$ & \multirow{3}{*}{$\begin{array}{l}\text { Historical } \\
\text { monuments }\end{array}$} & Historical sites & \multirow{7}{*}{$\begin{array}{l}\text { Changes in water } \\
\text { levels }\end{array}$} \\
\hline $\mathrm{S} / \mathrm{C} 2$ & & $\begin{array}{l}\text { Archaeological } \\
\text { changes }\end{array}$ & \\
\hline S/C 3 & & $\begin{array}{l}\text { Palaeontological } \\
\text { changes }\end{array}$ & \\
\hline $\mathrm{S} / \mathrm{C} 4$ & \multirow{3}{*}{$\begin{array}{l}\text { Cultural } \\
\text { heritage }\end{array}$} & Cultural changes & \\
\hline S/C 5 & & $\begin{array}{l}\text { Land use } \\
\text { changes }\end{array}$ & \\
\hline S/C 6 & & Way of life & \\
\hline S/C 7 & \multirow[t]{3}{*}{$\begin{array}{l}\text { Human health } \\
\text { \& safety }\end{array}$} & $\begin{array}{l}\text { Changes in } \\
\text { disease } \\
\text { incidence }\end{array}$ & \\
\hline $\mathrm{S} / \mathrm{C} 8$ & & $\begin{array}{l}\text { Increase in } \\
\text { parasitic } \\
\text { disease }\end{array}$ & $\begin{array}{l}\text { Increase humidity } \\
\text { along shoreline, } \\
\text { changes in natural } \\
\text { vegetation }\end{array}$ \\
\hline $\mathrm{S} / \mathrm{C} 9$ & & $\begin{array}{l}\text { Risk of surface } \\
\text { water } \\
\text { contamination }\end{array}$ & $\begin{array}{l}\text { Heavy metals in } \\
\text { intermolecular } \\
\text { bonding of soils, } \\
\text { other pollutants }\end{array}$ \\
\hline $\mathrm{S} / \mathrm{C} 10$ & \multirow[t]{4}{*}{$\begin{array}{l}\text { Quality of } \\
\text { life }\end{array}$} & $\begin{array}{c}\text { Changes to well } \\
\text { being of life }\end{array}$ & \multirow[t]{4}{*}{$\begin{array}{l}\text { Maybe (US) or (DS) } \\
\text { countries }\end{array}$} \\
\hline $\mathrm{S} / \mathrm{C} 11$ & & $\begin{array}{l}\text { Changes to } \\
\text { quality of life }\end{array}$ & \\
\hline $\mathrm{S} / \mathrm{C} 12$ & & $\begin{array}{l}\text { Quality of } \\
\text { recreational } \\
\text { facilities }\end{array}$ & \\
\hline $\mathrm{S} / \mathrm{C} 13$ & & $\begin{array}{l}\text { Quantity of } \\
\text { recreational } \\
\text { facilities }\end{array}$ & \\
\hline ID & Category & Factor & Comments \\
\hline \multicolumn{4}{|c|}{ Economic/operational components maybe (US) or (DS) countries } \\
\hline $\mathrm{E} / \mathrm{O} 1$ & \multirow[t]{2}{*}{$\begin{array}{l}\text { Natural } \\
\text { resources }\end{array}$} & $\begin{array}{l}\text { Present use of } \\
\text { natural } \\
\text { resources }\end{array}$ & \\
\hline $\mathrm{E} / \mathrm{O} 2$ & & $\begin{array}{l}\text { Potential use of } \\
\text { natural } \\
\text { resources }\end{array}$ & $\begin{array}{l}\text { Increase recreation, } \\
\text { fishing, swimming }\end{array}$ \\
\hline E/O 3 & Employment & $\begin{array}{l}\text { Employment } \\
\text { opportunity }\end{array}$ & $\begin{array}{l}\text { Recreation facilities, } \\
\text { dam site }\end{array}$ \\
\hline $\mathrm{E} / \mathrm{O} 4$ & $\begin{array}{l}\text { Economic } \\
\text { development }\end{array}$ & $\begin{array}{l}\text { Economic } \\
\text { development- } \\
\text { transboundary }\end{array}$ & $\begin{array}{l}\text { Hydro-electricity } \\
\text { sales, recreational } \\
\text { opportunities }\end{array}$ \\
\hline
\end{tabular}




\section{Appendix 2 environmental Score (ES) of Grand \\ Ethiopian Renaissance Dam (GERD)}

\begin{tabular}{rrrrrrrrrllllllllr}
\hline ID & A1 & A2 & AT & B1 & B2 & B3 & BT & ES & ID & A1 & A2 & AT & B1 & B2 & B3 & BT & ES \\
\hline \multicolumn{2}{r}{ Physical/chemical components } \\
P/C 1 & 1 & -1 & -1 & 2 & 2 & 2 & 6 & -6 & P/C 16 & 4 & -2 & -8 & 3 & 3 & 3 & 9 & -72 \\
P/C 2 & 1 & -1 & -1 & 2 & 2 & 2 & 6 & -6 & P/C 17 & 4 & -3 & -12 & 3 & 3 & 3 & 9 & -108 \\
P/C 3 & 1 & -1 & -1 & 2 & 2 & 2 & 6 & -6 & P/C 18 & 4 & -3 & -12 & 3 & 3 & 3 & 9 & -108 \\
P/C 4 & 4 & -3 & -12 & 1 & 3 & 3 & 7 & -84 & P/C 19 & 4 & -3 & -12 & 3 & 3 & 3 & 9 & -108 \\
P/C 5 & 4 & -2 & -8 & 3 & 3 & 3 & 9 & -72 & P/C 20 & 4 & -3 & -12 & 3 & 3 & 3 & 9 & -108 \\
P/C 6 & 4 & -2 & -8 & 3 & 3 & 3 & 9 & -72 & P/C 21 & 4 & -3 & -12 & 3 & 3 & 3 & 9 & -108 \\
P/C 7 & 4 & -2 & -8 & 3 & 3 & 3 & 9 & -72 & P/C 22 & 4 & -2 & -8 & 3 & 3 & 3 & 9 & -72 \\
P/C 8 & 4 & -1 & -4 & 3 & 3 & 3 & 9 & -36 & P/C 23 & 4 & -2 & -8 & 3 & 3 & 3 & 9 & -72 \\
P/C 9 & 4 & -1 & -4 & 3 & 3 & 3 & 9 & -36 & P/C 24 & 4 & -3 & -12 & 3 & 3 & 2 & 8 & -96 \\
P/C 10 & 4 & -3 & -12 & 3 & 3 & 3 & 9 & -108 & P/C 25 & 4 & -3 & -12 & 3 & 3 & 2 & 8 & -96 \\
P/C 11 & 3 & -3 & -9 & 3 & 3 & 3 & 9 & -81 & P/C 26 & 4 & -3 & -12 & 3 & 3 & 3 & 9 & -108 \\
P/C 12 & 3 & -2 & -6 & 3 & 3 & 3 & 9 & -54 & P/C 27 & 3 & -3 & -9 & 3 & 3 & 3 & 9 & -81 \\
P/C 13 & 3 & -2 & -6 & 3 & 3 & 3 & 9 & -54 & P/C 28 & 2 & -1 & -2 & 3 & 3 & 3 & 9 & -18 \\
P/C 14 & 3 & -2 & -6 & 3 & 3 & 3 & 9 & -54 & P/C 29 & 4 & -3 & -12 & 3 & 3 & 3 & 9 & -108 \\
P/C 15 & 3 & -2 & -6 & 3 & 3 & 3 & 9 & -54 & P/C 30 & 4 & -3 & -12 & 3 & 3 & 3 & 9 & -108 \\
\hline
\end{tabular}

\begin{tabular}{|c|c|c|c|c|c|c|c|c|c|c|c|c|c|c|c|c|c|}
\hline ID & A1 & A2 & AT & B1 & B2 & B3 & BT & ES & ID & A1 & A2 & AT & B1 & B2 & B3 & BT & ES \\
\hline \multicolumn{18}{|c|}{ Biological/ecological components } \\
\hline $\mathrm{B} / \mathrm{E} 1$ & 3 & -2 & -6 & 3 & 3 & 3 & 9 & -54 & $\mathrm{~B} / \mathrm{E} 10$ & 4 & -3 & -12 & 3 & 3 & 3 & 9 & -108 \\
\hline $\mathrm{B} / \mathrm{E} 2$ & 3 & -2 & -6 & 3 & 3 & 2 & 8 & -48 & $\mathrm{~B} / \mathrm{E} 11$ & 4 & -2 & -8 & 3 & 3 & 3 & 9 & -72 \\
\hline $\mathrm{B} / \mathrm{E} 3$ & 3 & -2 & -6 & 3 & 3 & 2 & 8 & -48 & B/E 12 & 4 & -2 & -8 & 3 & 3 & 3 & 9 & -72 \\
\hline $\mathrm{B} / \mathrm{E} 4$ & 3 & -2 & -6 & 3 & 3 & 2 & 8 & -48 & B/E 13 & 3 & -2 & -6 & 3 & 3 & 2 & 8 & -48 \\
\hline B/E 5 & 4 & -3 & -12 & 3 & 3 & 3 & 9 & -108 & B/E 14 & 4 & -3 & -12 & 3 & 3 & 3 & 9 & -108 \\
\hline B/E 6 & 4 & -2 & -8 & 3 & 3 & 3 & 9 & -72 & B/E 15 & 4 & -3 & -12 & 3 & 3 & 3 & 9 & -108 \\
\hline $\mathrm{B} / \mathrm{E} 7$ & 4 & -2 & -8 & 3 & 3 & 3 & 9 & -72 & B/E 16 & 4 & -2 & -8 & 3 & 3 & 3 & 9 & -72 \\
\hline $\mathrm{B} / \mathrm{E} 8$ & 4 & -2 & -8 & 3 & 3 & 2 & 8 & -64 & B/E 17 & 4 & -2 & -8 & 3 & 3 & 2 & 8 & -64 \\
\hline B/E 9 & 4 & -2 & -8 & 3 & 3 & 2 & 8 & -64 & & & & & & & & & \\
\hline
\end{tabular}

\begin{tabular}{|c|c|c|c|c|c|c|c|c|c|c|c|c|c|c|c|c|c|}
\hline ID & A1 & A2 & AT & B1 & B2 & B3 & BT & ES & ID & A1 & $\mathrm{A} 2$ & AT & B1 & B2 & B3 & BT & ES \\
\hline \multicolumn{18}{|c|}{ Social/cultural components } \\
\hline $\mathrm{S} / \mathrm{C} 1$ & 2 & -2 & -4 & 3 & 3 & 2 & 8 & -32 & $\mathrm{~S} / \mathrm{C} 10$ & 4 & 3 & 12 & 3 & 3 & 3 & 9 & 108 \\
\hline $\mathrm{S} / \mathrm{C} 2$ & 2 & -2 & -4 & 3 & 3 & 2 & 8 & -32 & $\mathrm{~S} / \mathrm{C} 11$ & 4 & 3 & 12 & 3 & 3 & 3 & 9 & 108 \\
\hline $\mathrm{S} / \mathrm{C} 3$ & 2 & -2 & -4 & 3 & 3 & 2 & 8 & -32 & $\mathrm{~S} / \mathrm{C} 12$ & 3 & 3 & 9 & 3 & 3 & 2 & 8 & 72 \\
\hline $\mathrm{S} / \mathrm{C} 4$ & 4 & 2 & 8 & 3 & 3 & 3 & 9 & 72 & $\mathrm{~S} / \mathrm{C} 13$ & 3 & 3 & 9 & 3 & 3 & 2 & 8 & 72 \\
\hline S/C 5 & 4 & -2 & -8 & 3 & 3 & 3 & 9 & -72 & $\mathrm{~S} / \mathrm{C} 14$ & 4 & -3 & -12 & 3 & 3 & 3 & 9 & -108 \\
\hline S/C 6 & 4 & 2 & 8 & 3 & 3 & 3 & 9 & 72 & S/C 15 & 4 & -2 & -8 & 3 & 3 & 3 & 9 & -72 \\
\hline S/C 7 & 3 & -1 & -3 & 2 & 2 & 2 & 6 & -18 & $\mathrm{~S} / \mathrm{C} 16$ & 3 & -2 & -6 & 3 & 3 & 2 & 8 & -48 \\
\hline S/C 8 & 3 & -2 & -6 & 3 & 2 & 2 & 7 & -42 & S/C 17 & 3 & -2 & -6 & 3 & 3 & 2 & 8 & -48 \\
\hline S/C 9 & 4 & -3 & -12 & 3 & 3 & 3 & 9 & -108 & & & & & & & & & \\
\hline
\end{tabular}

S/C 10, 11, $12 \& 13$ for (US) countries where S/C 14, 15, 16 \& 17 for (DS) countries 


\begin{tabular}{|c|c|c|c|c|c|c|c|c|c|c|c|c|c|c|c|c|c|}
\hline ID & A1 & A2 & AT & $\mathrm{B} 1$ & B2 & B3 & BT & ES & ID & A1 & A2 & AT & $\mathrm{B} 1$ & B2 & B3 & BT & ES \\
\hline \multicolumn{18}{|c|}{ Economic/operational components } \\
\hline $\mathrm{E} / \mathrm{O} 1$ & 4 & 3 & 12 & 3 & 3 & 2 & 8 & 96 & E/O 5 & 4 & -3 & -12 & 3 & 3 & 2 & 8 & -96 \\
\hline $\mathrm{E} / \mathrm{O} 2$ & 4 & 3 & 12 & 3 & 3 & 3 & 9 & 108 & E/O 6 & 4 & -3 & -12 & 3 & 3 & 3 & 9 & -108 \\
\hline $\mathrm{E} / \mathrm{O} 3$ & 4 & 3 & 12 & 3 & 3 & 3 & 9 & 108 & E/O 7 & 4 & -3 & -12 & 3 & 3 & 3 & 9 & -108 \\
\hline $\mathrm{E} / \mathrm{O} 4$ & 4 & 3 & 12 & 3 & 3 & 3 & 9 & 108 & E/O 8 & 4 & -2 & -8 & 3 & 3 & 3 & 9 & -72 \\
\hline
\end{tabular}

E/O 1, 2, 3 \& 4 for (US) countries where E/O 5, 6, 7 \& 8 for (DS) countries

\section{References}

Adelle C, Weiland S (2012) Policy assessment: the state of the art. Impact Assess Proj Apprais 30(1):25-33

Ansar A, Flyvbjerg B, Budzier A, Lunn D (2014) Should we build more large dams? The actual costs of hydropower megaproject development. Energy Policy 69:1-14

Batisha AF (2013) Sustainability assessment of grand renaissance dam: regarding landslides in Ethiopia. IJS 2(1):25-38

Bruch C, Nakayama M, Troell J, Goldman L, Mrema EM (2008) Assessing the assessments: improving methodologies for impact assessment in transboundary watercourses. Impact Assess Proj Apprais 26(4):239-251

De Montis A (2014) Strategic environmental assessment of energy planning tools. A study of Italian regions and provinces. Environ Impact Assess Rev 46:32-42

Esteves Ana Maria, Franks Daniel, Vanclay Frank (2012) Social impact assessment: the state of the art. Impact Assess Proj Apprais 30(1):34-42

Fundingsland Tetlow M, Hanusch M (2012) Strategic environmental assessment: the state of the art. Impact Assess Proj Apprais 30(1):15-24

Hanna P, Vanclay F, Langdon EJ, Arts J (2014) Improving the effectiveness of impact assessment pertaining to Indigenous peoples in the Brazilian environmental licensing procedure. Environ Impact Assess Rev 46:58-67

Harris-Roxas Ben, Viliani Francesca, Bond Alan, Cave Ben, Divall Mark, Furu Peter, Harris Patrick, Soeberg Matthew, Wernham Aaron, Winkler Mirko (2012) Health impact assessment: the state of the art. Impact Assess Proj Apprais 30(1):43-52

Ijäs A, Kuitunen MT, Jalava K (2010) Developing the RIAM method (rapid impact assessment matrix) in the context of impact significance assessment. Environ Impact Assess Rev 30(2):82-89

International Rivers (2013) Field Visit Report on the Grand Ethiopian Renaissance Dam, http://www.internationalrivers.org/resources/ field-visit-report-on-the-grand-ethiopian-renaissance-dam-7815. Accessed on 3/3/2014

Kim E, Song W, Lee D (2013) A multi-scale metrics approach to forest fragmentation for strategic environmental impact assessment. Environ Impact Assess Rev 42:31-38

Kuitunen M, Jalava K, Hirvonen K (2008) Testing the usability of the Rapid Impact Assessment Matrix (RIAM) method for comparison of EIA and SEA results. Environ Impact Assess Rev 28(4):312-320

Li W, Xie Y, Hao F (2014) Applying an improved rapid impact assessment matrix method to strategic environmental assessment of urban planning in China. Environ Impact Assess Rev 46:13-24

Masden EA, Fox AD, Furness RW, Bullman R, Haydon DT (2010) Cumulative impact assessments and bird/wind farm interactions: developing a conceptual framework. Environ Impact Assess Rev 30(1):1-7

Morgan RK (2012) Environmental impact assessment: the state of the art. Impact Assess Proj Apprais 30(1):5-14
Morrison-Saunders A, Pope J (2012) Sustainability assessment: the state of the art. Impact Assess Proj Apprais 30(1):53-62

Pastakia CMR, Jensen A (1998) The rapid impact assessment matrix (RIAM) For EIA. Environ Impact Assess Rev 18(5):461-482

Phillips J (2015) A quantitative-based evaluation of the environmental impact and sustainability of a proposed onshore wind farm in the United Kingdom. Renew Sustain Energy Rev 49:1261-1270

Pintér L, Hardi P, Martinuzzi A, Hall J (2012) Bellagio STAMP: Principles for sustainability assessment and measurement. Ecol Indic 17:20-28

Prenzel PV, Vanclay F (2014) How social impact assessment can contribute to conflict management. Environ Impact Assess Rev 45:30-37

Rashmi MKM, Dasgupta BV (2010) EIA of municipal solid waste disposal site in Varanasi using RIAM analysis. Res Conserv Recycl 54(9):541-546

Raslanas S, Stasiukynas A, Jurgelaityt E (2013) Sustainability assessment studies of recreational buildings. Procedia Eng 57(2013):929-937

Schoeters M (2013) An analysis of a big dam project: the Grand Ethiopian Renaissance Dam, Ethiopia. Master Thesis, Faculty of political and social sciences, Ghent University

Shakib-Manesh TE, Hirvonen KO, Jalava KJ, Ålander T, Kuitunen MT (2014) Ranking of small scale proposals for water system repair using the rapid impact assessment matrix (RIAM). Environ Impact Assess Rev 49:49-56

Suthar S, Sajwan A (2014) Rapid impact assessment matrix (RIAM) analysis as decision tool to select new site for municipal solid waste disposal: a case study of Dehradun city, India. Sustain Cities Soc 13:12-19

Taheri M, Gholamalifard M, Ghazizade MJ, Rahimoghli S (2014) Environmental impact assessment of municipal solid waste disposal site in Tabriz, Iran using rapid impact assessment matrix. Impact Assess Proj Apprais 32(2):162-169

The International Commission on Large Dams (ICOLD) The Position Paper on Dams and the Environment. http://www.icold-cigb.org/ GB/Dams/dams_environment.asp. Accessed on 2/2/2014

Toroa J, Requenab I, Duartec O, Zamoranod M (2013) A qualitative method proposal to improve environmental impact assessment. Environ Impact Assess Rev 43:9-20

UNEP, Economic Commission for Europe (UNECE), and European Bank for Reconstruction and Development (EBRD) (2003) Guidelines on environmental impact assessment in a transboundary context in the Caspian Sea Region-Step by step procedures. United Nations Environment Programme, Regional Office for Europe, Geneva

Upham P, Smith B (2014a) Using the rapid impact assessment matrix to synthesize biofuel and bioenergy impact assessment results: the example of medium scale bioenergy heat options. J Clean Prod 65(15):261-269

Upham P, Smith B (2014b) Using the rapid impact assessment matrix to synthesize biofuel and bioenergy impact assessment results: the example of medium scale bioenergy heat options. J Clean Prod 65:261-269 